\begin{tabular}{|l|l|l|}
\hline \multicolumn{2}{|c|}{ PublisherInfo } \\
\hline \hline PublisherName & $:$ & BioMed Central \\
\hline \hline PublisherLocation & $:$ & London \\
\hline \hline PublisherImprintName & $:$ & BioMed Central \\
\hline \hline
\end{tabular}

\title{
2002 Gairdner International Awards announced
}

\begin{tabular}{|l|l|l||}
\hline \multicolumn{2}{|c|}{ ArticleInfo } \\
\hline \hline ArticleID & $:$ & 4459 \\
\hline \hline ArticleDOI & $:$ & $10.1186 /$ gb-spotlight-20020424-01 \\
\hline \hline ArticleCitationID & $:$ & spotlight-20020424-01 \\
\hline \hline ArticleSequenceNumber & $:$ & 125 \\
\hline \hline ArticleCategory & $:$ & Research news \\
\hline \hline ArticleFirstPage & $:$ & 1 \\
\hline \hline ArticleLastPage & $:$ & 2 \\
\hline \hline & & RegistrationDate : 2002-4-24 \\
\hline ArticleHistory & $:$ & OnlineDate \\
\hline \hline ArticleCopyright & $:$ & BioMed Central Ltd2002-24 \\
\hline \hline ArticleGrants & $:$ & \\
\hline \hline ArticleContext & $:$ & 130593311 \\
\hline \hline
\end{tabular}




\section{David Bruce}

Email: davidb@biomedcentral.com

The announcement today of the 2002 International Gairdner Awards (sponsored by Genome Canada) honors eight individuals central to the success of the Human Genome Project. The citation highlights their "major original and pioneering contributions, both fundamental and applied to our understanding of mammalian and other genomes." In a field to which so many have contributed, the precise merits of the winners seem likely to occupy many fine minds in coming weeks.

The General Genome Citation is broken down into three areas: Maynard Olson, James Watson and Jean Weissenbach are recognized as the "early architects"; Eric Lander, John Sulston, Robert Waterston and Craig Venter are honored for their "seminal contributions to sequencing of human and other genomes"; and the bioinformaticians Philip Green and Michael Waterman receive the award for developing the computational molecular biology tools that were vital for analyzing the enormous amount of data generated by the sequencing projects. "The study of genomics, proteomics and bioinformatics will surely lead to major breakthroughs in medicine and health - from the discovery of the genesis of disease to the design and delivery system of new treatments, " said John Dirks, president of the Gairdner Foundation.

In addition, James Watson was honored with an International Award of Merit for "His 50 years of unparalleled contributions to biology and medical science, and in particular for his critical international leadership during the creation of the Human Genome Project."

The Foundation, established in 1957 by Toronto businessman James Gairdner, first recognized achievement in medical science in 1959. Over the past 42 years, the awards have grown to be one of the most prestigious international awards in medical research. Each winner receives $\$ 30,000$. Of the past 255 international awardees in a variety of disciplines from genetic research to cancer therapy, 56 have gone on to win a Nobel Prize.

\section{References}

1. The Gairdner Foundation, [http://www.gairdner.org]

2. Genome Canada, [http://www.genomecanada.ca]

3. Nobel Prize, [http://www.nobel.se/nobel/index.html] 